\title{
"Profoundly disappointing" UK science budget allocated
}

\section{London}

By choosing to ignore recommendations for a greater investment in the science base, the British government has seriously prejudiced the country's future social and economic development, the Advisory Board for the Research Councils (ABRC) has said in its official reaction to last November's announcement of the science budget (see Nature 330, 101; 1987). The board, whose job is to advise the education secretary on his responsibilities for civil science and how to divide the science budget among the five councils, describes as "dismal" the present financial status of British academic science.

The comments are contained in the board's formal advice on the allocation of the science budget for 1988-89 to 1990-91. The budget provides for an increase of $£ 50$ million to $£ 699$ million for $1988-89$, with a planning figure of $£ 729$ million for each of the next two years - increases of $£ 65$ million and $£ 48$ million, respectively, on previous plans.

ABRC chairman Sir David Phillips says in his covering letter to the education secretary, Mr Kenneth Baker, that the board was "profoundly disappointed" that the increases" were "insufficient either to avert a reduction in the volume of scienti-

\section{NERC cuts back}

\section{London}

BrITAIN's Natural Environment Research Council (NERC) is preparing to implement severe cost-cutting measures in the face of a decline in income from research commissioned by government departments.

If the government accepts recommendations on allocation of the science vote, NERC will receive in 1988-89 $\$ 90.6$ million, a decline in real value of $£ 2.5$ million on this year's grant. The value of commissioned income is expected to fall by $£ 4.1$ million, caused by a decline of $£ 4.6$ million in government commissions, but offset by an increase of $£ 500,000$ in non-government commissions. Other income is expected to fall by $£ 700,000$, partly because of withdrawal of the Department of Energy's contribution to the Ocean Drilling Program.

The situation is a particularly bitter pill for NERC to swallow in view of its successful attempts to attract income from non-governmental sources. Such income has trebled in the past three years to around $£ 9$ million.

NERC will be looking to shed around 120 jobs from a total workforce of some 2,700 , and may have to resort to compulsory redundancies. It will be forced to reduce its support of research in universities by $£ 700,000$ as well as scrapping a planned increase of $£ 1.9$ million. Building work at the British Geological Survey headquarters in Nottingham will be delayed. No new special topic programmes will start this year, and spending on big computers is deferred. fic activity or to allow for the strategic reshaping of the science base". Comments accompanying the allocation advice itself will leave the government in little doubt of the level of bitter frustration that the scientific community is experiencing. The advice concludes: "The government's revised expenditure plans for the science budget do not provide the means to move our nation's scientific capability towards the twenty-first century. We remain precariously poised at the divide and are beginning to slip in the wrong direction. A great opportunity has been sadly missed."

The board calculates that relative to the government's forecasts of inflation in the economy as a whole, the new science expenditure plans imply increases of 1.3 per cent in 1988-89, a further 1.2 per cent the following year, and a reduction of 3 per cent in 1990-91. Of the extra money, $£ 14$ million is earmarked for Antarctic and AIDS research, which if set aside results in a decline in science expenditure of about 0.2 per cent in each of the first two years, with no change in 1990-91. But because of the exceptionally high costs of scientific research, the board expects a 2 per cent reduction in scientific activity for this and between 2 and 3 per cent less in 1990-91, compared with an anticipated

\section{Three more centres}

\section{London}

Britain's Science and Engineering Research Council (SERC) last week announced a further three interdisciplinary research centres. The universities of Glasgow, Liverpool and Oxford will host the centres for engineering design, surface science and molecular sciences, respectively. The three centres will receive government funding of at least $£ 5$ million each over their first six years; the precise sum allocated will depend on the contribution of putative industrial partners in the centres' research programmes. The first research centre, to investigate small devices applications of high-temperature superconductivity, was announced at the end of last year, based at the University of Cambridge.

The concept of university research centres, to provide a focus for the development of research programmes in interdisciplinary topics of strategic importance, has the firm backing of the government. For several months SERC has been considering some 80 bids for centres in seven strategic areas of science. Of the four centres supported, about half the money has come from SERC's own resources, and about half from allocations by the Advisory Board for the Research Councils.

A fifth centre, in synthesis and characterization of semiconductor and novel materials, has been approved in principle to be established at a University of London consortium based at Imperial College. The centre will be set up when enough money becomes available. cumulative growth of 8 per cent in the country's gross domestic product. "Basic and strategic scientific research will thereby become an even smaller part of our national effort", the board says.

The ABRC had asked for an extra $£ 103$ million, $£ 131$ million and $£ 166$ million for each of the next three years, principally to restructure academic scientific research and teaching. The board points out that committed expenditures will absorb nearly all the money available, with next year's pay awards estimated at around $£ 30$ million.

The board recommends that the Natural Environment Research Council

UK science budget allocation 1988-89 (£million) Research councils

$\begin{array}{lr}\text { Agricultural \& Food } & 58.44 \\ \text { Economic \& Social } & 27.66 \\ \text { Medical } & 146.68 \\ \text { Natural Environment } & 90.86 \\ \text { Science \& Engineering } & 366.28 \\ \text { ther bodies } & \\ \text { Royal Society } & 7.94 \\ \text { Fellowship of Engineering } & 0.75 \\ \text { Science Policy Studies } & 0.10 \\ \text { Centre for Exploitation of Science } & \\ \quad \text { and Technology } & 0.08 \\ \text { otal } & \mathbf{6 9 8 . 7 9}\end{array}$

receives $£ 3$ million this year to cover restructuring costs, including targetted redundancies, arising from a reduction in commissioned research from government departments (see below). A further $£ 2$ million may be required in 1989-90, the board says, money that "will not buy science". A request from the Medical Research Council for an increased allocation for AIDS-related clinical and pathological studies cannot be met.

In all, the sum available for new initiatives this year is only $£ 7.5$ million, the main priority for which is the establishment of interdisciplinary university research centres. The board recommends that the Science and Engineering $\mathrm{Re}$ search Council (SERC) be allocated $£ 2.8$ million in $1988-89$, and $£ 5$ million and $£ 3$ million in the following two years to fund a further two research centres on top of the one in superconductivity which it had already announced (see left).

The board also recommends an allocation of $£ 0.3$ million, rising to $£ 4.2$ million to the Medical Research Council for its proposal to establish a research centre in toxicology. The Agricultural and Food Research Council should receive an extra $£ 1.5$ million in $1989-90$ and $1990-91$ to spend on research in the universities, the board says.

The board welcomes the government's LINK programme, (see Nature 331, 473; 1988) to encourage collaborative research between industry and the academic community. The board recommends that SERC be allocated a further $£ 1.1$ million in the coming year and $£ 2$ million in later years to support further LINK programmes.

Simon Hadlington 